\begin{tabular}{|c|c|c|}
\hline A & $\begin{array}{c}\text { International Journal of Current Research } \\
\text { and Academic Review }\end{array}$ & \\
\hline $\begin{array}{l}\text { EXCELLENT } \\
\text { PUBLISHERS }\end{array}$ & $\begin{array}{c}\text { ISSN: 2347-3215 (Online):,;Volume 5:,;Number } 6 \text { (June-2017) } \\
\text { Journal homepage: http://www.ijcrar.com }\end{array}$ & \\
\hline
\end{tabular}

doi: https://doi.org/10.20546/ijcrar.2017.506.012

\title{
Fossil Pteridophytes-A Review
}

\section{Teena Agrawal* and Priyanka Danai}

\author{
Banasthali University, Niwai, India
}

*Corresponding author

\begin{abstract}
Evolution of the plants is the very important aspects of the life on the planet. Since early plant life was typically aquatic in nature. It was the assemblage of many kinds of the aquatic algae and the other taxa of the aquatic importance. Among them the bryophytes are the plants which were amphibious in nature. However the pteridophytes are typically land plants having well developed vascular bundles as well as other features of the and adaptations. Pteridophytes have the long fossils history and plants were well developed in the whole Palaeozoic era. They were flourished well in the late Devonian and the carboniferous period. In that era one can find a number of the examples of the fossils plants which were intimidate in evolution of the many kinds of the organs. Lepidocarpales was the assemblage of the organs like structure which have the pioneer symptoms of the evolution of the ovules. This review presents the assemblage of the fossil pteridophytes.
\end{abstract}

\section{Article Info}

Accepted: 05 June 2017

Available Online: 20 June 2017

\section{Keywords}

Fossils pteridophytes,

Evolution,

Adaptations,

Land plants.

\section{Introduction}

The pteridophytes formed the dominant part of the vegetation in the historic past. It was the middle of the Paleozoic era when these plants group was ell flourished in every places. These flora of the pteridophytes was very abundant till early mesozoic but mesozoic era was well dominated by the gymnosperms. In modern day the pteridophytes flora is replaced by the spermatophytes. These spermatophytes involved the gymnosperms and the angiosperms. Present era is the best flourished by the angiosperms.

In whole world the pteridophytes are now of the relict in distribution. They are restricted to the some of the tropical rain forest and the northern hemisphere of the world. However in India the pteridophytes are distributed in to the Himalayas and the Nilgiris. Here large very beautiful tree ferns can be seen with good physiognomy, similarly epiphytic ferns and the other hanging club mosses can be seen in the Nilgiri hills. In India, 500 species of the ferns can be seen with differ kinds of the pattern of the foliage, which are the taxonomic significance in nature.

Pteridophytes plants have the long fossils history. They have been recognised in the late Silurian period of the Paleozoic era. These plants have the dominant vegetation in whole of the Paleozoic era. The middle and the late palaeozoic era can be regarded as the age of ferns or ages of pteridophyta. The giant lycopsida and the horse tails and the arborescent tree ferns dominated the whole biota at that time. The pteridophytes which are presented by the lycopsida $\mathrm{n}$ sphenopsida and the pteridopsida which are of the length of the maximum 6 to 7 feet's were very abundant in distribution and in height of the trees. They 
were reportedly around 120 feet's at the time of the palaeozoic era. They were very abundant and highly in whole vegetation. This era was the evolution of the pteridophytes and the evolution of the gymnosperms. However in today world they are represented only by the some relict genera and the relict fossils evidences (Table $1)$.

That era was dominated by the lepidodendron, sigilalria and the calamites and other fossil lycopsids of that era.

However distribution of the ferns was the matter of the slightly ambiguity, since ferns were of less diversity in the Paleozoic era but as the evolution proceeds and the time passes the diversity of the ferns increase, well a number of the ferns can be seen in that era with great diversity.

In India the fossil pteridophyes are studied by the Surange (1966) in detail. He has given the whole account of the places in India, which have the long distribution of the fossils pteridophytes. Among the four classes of the pteridophytes like psilopsida, lycopsida and sphenopsida and pteriopsida, he has described the one of the member of the psilophyta, seven fossil members of the lycopodiophyta, 12 members of the sphenophyta, 66 members of thepteriphyta. A large number of the fossil ferns have been described in the Rajmahal hills of the India. Bose, Sah and Sharma (1967) have described a number of the fossil ferns from the Bihar and other hills of the India. Suthar and Sharma (1968) reconstruct the whole Solenopteris form the Jurrasic flora of the Rajmahal hills (Fig. 1).

They found the plant in the form of the leaves, stems, flower, and the seeds in different forms. These plants organs have been termed with different terminology.

In India the Gondwana land was the point of distribution of the many fossil ferns and horse tails. Glossopteris flora of the Mesozoic was constituted by the many different genera of the sphenophyta of the pteridophyta.

Some the detailed account of the fossils pteridophyta is described below.

Fossil psilophtales is the new class which has the assemblages of the fossil plants. This class was coined in the era of the 1917. In that class few genera was included like the rhynia, horneophyton and psilophytlaes. These plants were distributed during the late Silurian and the Devonian and the Upper Carboniferous period. These plants lack true roots, leaves and the other structures. However developed vascular system can be seen in these groups. Psilophytles are totally different from the other similarly named class termed as the psilotales.

The plant was described by the Kingston and Lang (1917) in the Rhynia chart of the British islands. The plant was found in different stem, leaves and the isolated sporangia. Typical dichotomous division can be seen in the stems of the Rhynia plants (Fig. 2).

Horneophyton is the fossil pteridophytes and it is the linkage between the fossil psilotales and the other living members' of the spehopsida. These members were also reported form the rhynia chart of the scotlands in 1920. The sporophytes body is dichotomous in division and the sporangium having the central columella, $\mathrm{s}$ and the other organs of the sores in sides.

The presence of the columella in the hornea is the primitive features of the bryophytes whereas the presence of the tracheids in the sporangia is the presence and the development of the vascular tissue shows the resemblance with the higher plants.

Rhynia and horniophyton has been reported form the early Devonian period of the rhynia chart of the Scotland. These were the giant and the wet ecosystem of that era (Fig. 3).

Fossil lycopsida: Lycopsida is the class lycopodiales has the assemblage of the living and the fossil genera. This is one of the oldest lineages of the fossil genera and the branches. In these fossil genera's typical heterospory and the alternation of the generation can be seen with clear examples. Some of the fossil genera's are enlisted in these orders as,

1. Lepidodendrales

2. Isoetales

3. Zosterophyllaeles

Lepidodendrales has the long fossil history, with primitive vascular and arbores cent plants related to the lycopsida. These plant groups were well flourished in the late Carboniferous period, however rapid declines of the lepidodendrales can be seen during the Mesozoic era. These plants group reached to the height up to the 30-40 meters during the Devonian and the late Silurian periods.

Lepidodendrales has the long trunk, which reached the height up to the some 40 meters, it was unbranched as 
well as it bifurcates at the top of the branches (Fig. 5). At the top of the branches one can see the crown of the braches which differentiate it from the rest of the group. Some of the genera of the lepidodendrlaes are enlisted as.

\section{Lepidodendron \\ 2. Lepiodpholeois \\ 3. Sigillaria}

Lepidodendron reproductive structures has-been found in the form of the cones or the separated sporangia. These have been termed as the lepidostrobus. These cones has always been found in the form of the cones and isolated, not in the form of the attached part of the lepidodendron stem (Fig. 4).

Fossils spenopsida: Spenopsida is the class of the assemblage of the fossil and the living pteidophytes, going back to the late devonian period, these plants commonly known as the horse tails. Living horse tails are representatives of the genus equisetum, which are represented by the 20 species, these species grows in to the humid areas and generally in to the groups. The vertical stem is represented by the crowns of the leaves, which are present in the alternate sequences of the stem having the ridges' and the furrows.

Table.1 shows geological time scale distribution of plants

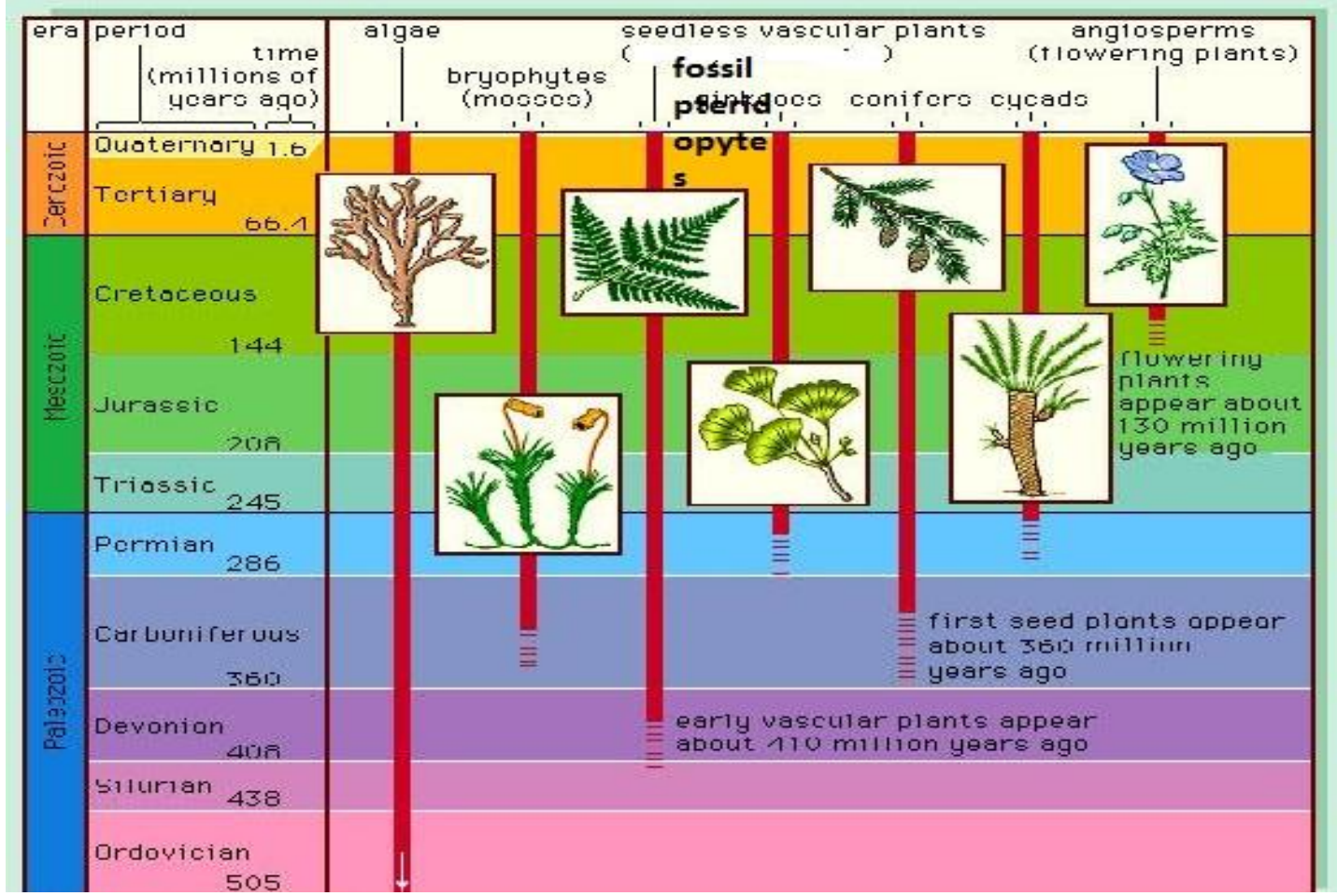

Fig.1

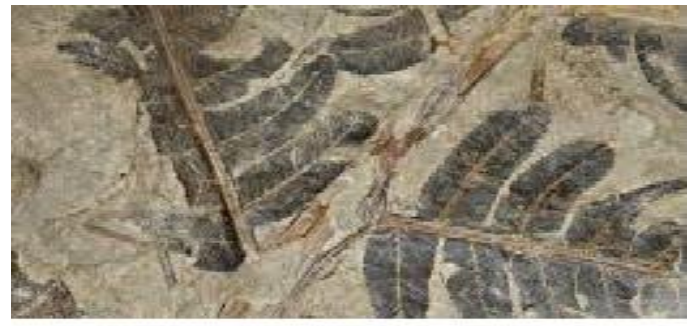


Fig.2

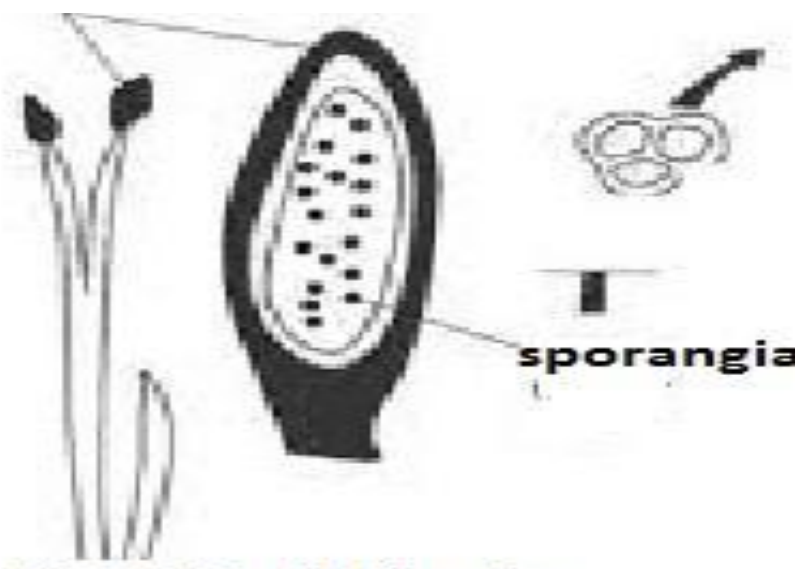

Fig :2 Fossil Rhynia

Fig.3

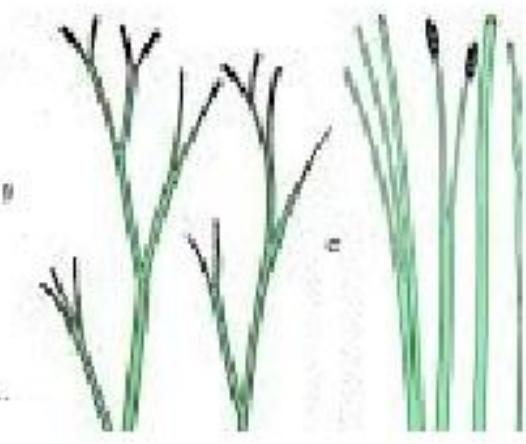

Fig :3 Horneophyton

Fig.4

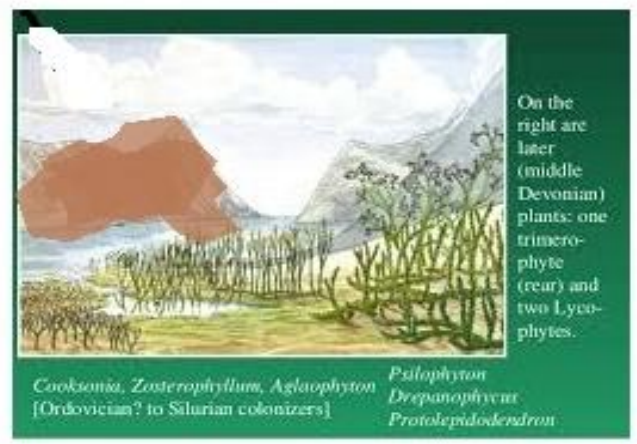

fig :4 reconstruction of the lepidodendron world 
Fig.5

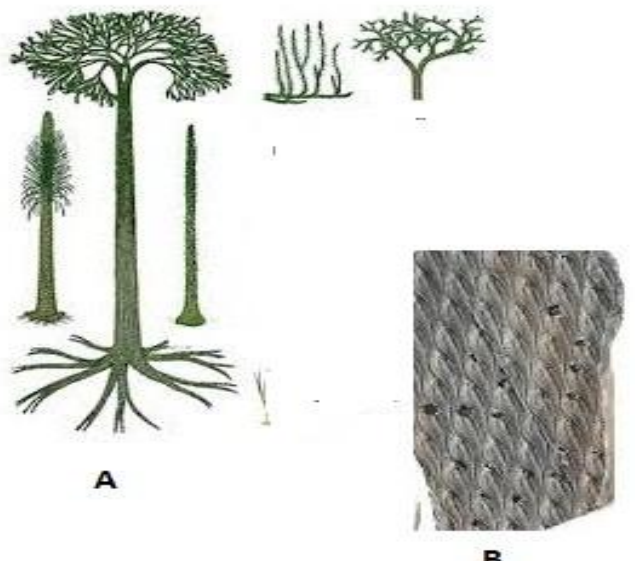

B

Fig;5 arborescent giant lepidodenrlaes, $A$

B,Fossil imagesof the cones

Fig.6

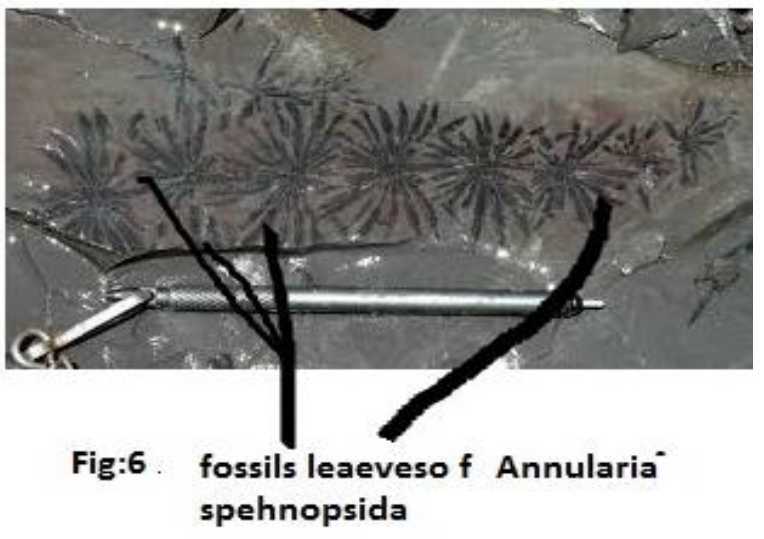

Fig.7

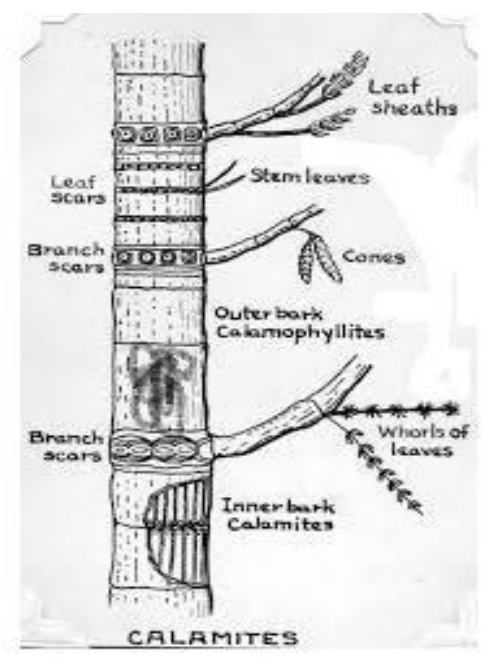

Fig:7 fossil calamites stem 
Calamitales are the fossils pteridophytes which were arborescent in the devonian period, whole and the giant forest of the calamitales can be seen in the at that era (Fig. 7). They were the dominant vegetation of the understory of the coal swamps of the carboniferous period.

A number of the organ taxa have been identified, whole plants are not reported so frequently. Calamites is the name of the fossil stem, other fossil organ genra are enlisted as:

1) Arthropitys

2) Astromylon

3) Annularia

Annularia is the name of the leaves of the calamites stems (Fig. 6). They were arranged in the form of the whorls in the group of the 8-11. They were also reported in the form of the separated organs never found attached in any body. Several fragments of the rocks containing prints of fern like foliage. Pteriopsida were found in the non technical private collection of rocks, and minerals of costarica (Luis Diego Gomez, 1968). The rocks were collected in the Rio general valley by personal of aluminium of America. The matrix proved to be the dark grey luciteberlonging to the terraba formations. After the review of the literatures the ferns like organism were found to be the pteropsida.

\section{References}

Angiosperm Phylogeny Group [APG III]. 2009. An update of the Angiosperm Phylogeny Group classification for the orders and families of flowering plants: APG III. Botanical J. Linnean Society, 161: 105-121.

Bailey, F.M. 1881. The Fern World of Australia: with homes of the Queensland species. Gordon \& Gotch, Brisbane, $105 \mathrm{pp}$.

Baker, J.G. 1881. On a collection of ferns made by $\mathrm{Mr}$. W. Kalbreyer in New Grenada. Trimen's J. Botany, British and foreign 19 (new series 10): 202-208.

Baker, J.G. 1891. A summary of the new ferns which have been discovered or described since 1874 . Annals of Botany, (Oxford) 5: 455-500.

Ballard, F. 1945. A new fern genus from Mexico and Guatemala. American Fern J., 35: 1-3.

Beck, J.B., Windham, M.D., Yatskievych, G. \& Pryer, K.M. 2010. A diploids-first approach to species delimitation and interpreting polyploid evolution in the fern genus Astrolepis (Pteridaceae). Systematic Bot., 35: 223-234.

Bernhardi, D.I.I. 1801. Tentamen alterum filices in genera redigendi. J. für die Botanik (Schrader), 1800(2): 121-136.

Bierhorst, D.W. 1977. The systematic position of Psilotum and Tmesipteris. Brittonia, 29: 3-13.

Boodle, L.A. 1915. XXVI. -Thyrsopteris elegans (with plate). Bulletin of Miscellaneous Information Royal Botanic Garden Kew, 1915: 295-296.

Bower, F.O. 1923. Studies in phylogeny of the Filicales VIII. On Loxsoma and Loxsomopsis. Annals of Bot., 37: 349-354.

Brown, E.D.W. \& Brown, F.B.H. 1931. Flora of southeastern Polynesia, II: Pteridophytes. Bernice Pauahi Bishop Museum Bull., 89: 1-123.

Brown, R. 1810. Prodromus Florae Novae Hollandiae et Insulae Van-Diemen, etc. Leornard Schrag, Nuremberg.

Brownsey, P.J. \& Lovis, J.D. 1987. Chromosome numbers for the New Zealand species of Psilotum and Tmesipteris, and the phylogenetic relationships of the Psilotales. New Zealand J. Botany, 25: 439454.

Chambers, T.C. 2008. Doodia hindii (Blechnaceae) a new species from north eastern New South Wales, Australia. Telopea, 12: 257-261.

Chase, M.W. \& Reveal, J.L. 2009. A phylogenetic classification of the land plants to accompany APG III. Botanical J. Linnean Soc., 161: 122-127.

Ching, R.C. 1940. On natural classification of the family "Polypodiaceae". Sunyatsenia, 5: 201-268.

Christ, H. 1897. Die Farnkräuter der Erde: beschreibende Darstellung der Geschlechter und wichtigeren Arten der Farnpflanzen mit besonderer Berücksichtigung der Exotischen. G. Fischer, Jena.

Christ, H. 1904. Primitiae Florae Costaricensis. Filices \& Lycopodiaceae III. Bulletin de l'Herbier Boissier, sér. 2, 4: 936-951, 957-972, 1089-1104.

Christenhusz, M.J.M. 2007. Evolutionary history and taxonomy of neotropical marattioid ferns: studies of an ancient lineage of plants. Annales Universitatis Turkuensis ser. AII, vol. 216: 1-134.

Christenhusz, M.J.M. 2009a. Index Pteridophytorum Guadalupensium, a revised checklist of the club mosses and ferns of Guadeloupe (French West Indies). Botanical J. Linnean Soc., 161: 213-277.

Christenhusz, M.J.M. 2009b. New combinations and an overview of Cyathea subg. Hymenophyllopsis (Cyatheaceae). Phytotaxa, 1: 37-42.

Christenhusz, M.J.M. 2010a. Danaea (Marattiaceae) revisited: biodiversity, a new classification and ten 
new species of a neotropical fern genus. Botanical $J$. Linnean Soc., 163: 360-385.

Christenhusz, M.J.M. 2010b. New combinations in the fern genus Tectaria (Tectariaceae) for the Flora of China. Phytotaxa, 10: 58-59.

Christenhusz, M.J.M., Tuomisto, H., Metzgar, J.S. \& Pryer, K.M. 2008. Evolutionary relationships within the Neotropical, eusporangiate fern genus Danaea (Marattiaceae). Mol. Phylogenetics and Evol., 46: 34-48.

Christensen, C. \& Skottsberg, C. 1920. The ferns of Easter Island. The natural history of Juan Fernandez and Easter Island, vol. 2: 47-54. Almqvist \& Wiksells Boktryckeri, Uppsala.

Christensen, C. 1906. Index filicum, sive Enumeratio omnium generum specierumque filicum et Hydropteridum ab anno 1753 ad finem anni 1905 descriptorium: adjectis synonymis principalibus, area geographica, etc. H. Hagerup, Copenhagen.

Christensen, C. 1910. Ueber einige Farne in O. Swartz' Herbarium. Arkiv för Botanik, 9(11): 1-46.

Churchill, H., Tryon, R. \& Barrington, D.S. 1998. Development of the sorus in tree ferns: Dicksoniaceae. Canadian J. Bot., 76: 1245-1252.

Colenso, W. 1881. On some new and undescribed New Zealand Ferns. Transactions of the New Zealand Institute, 13: 376-384.

Conant, D.S. \& Stein, D.B. 2001. Phylogenetic and geographic relationships of the tree ferns (Cyatheaceae) on Mount Kinabalu. Sabah Parks Nat. J., 4: 25-43.

Conant, D.S., Raubeson, L.A., Attwood, D.K. \& Stein, D.B. 1995. The relationships o Papuasian
Cyatheaceae to New World tree ferns. American Fern J., 85: 328-340.

Conant, D.S., Raubeson, L.A., Attwood, D.K., Perera, S., Zimmer, E.A., Sweere, J.A. \& Stein, D.B. 1996. Phylogenetic and evolutionary implications of combined analysis of DNA and morphology in the Cyatheaceae. Pp. 231-248, in: Camus, J.M., Gibby, M. \& Johns, R.J. (eds.), Pteridology in Perspective, Royal Botanic Gardens, Kew.

Copeland, E.B. 1929. Pteridophyta Novae Caledoniae. University of California Publications in Botany 14: 353-369.

Copeland, E.B. 1947. Genera Filicum. Chronica Botanica, Waltham, Massachusetts.

Crabbe, J.A., Jermy, A.C. \& Mickel, J.T. 1975. A new generic sequence for the pteridophyte herbarium. Fern Gazette, 11: 141-162.

Cranfill, R.B. \& Kato, M. 2003. Phylogenetics, biogeography and classification of the woodwardioid ferns (Blechnaceae). Pp. 25-48, in: Chandra, S. \& Srivastava, M. (eds.), Pteridology in the New Millennium. Kluwer Academic Publishers, Dordrecht.

Cranfill, R.B. 2001. Phylogenetic Studies in the Polypodiales (Pteridophyta) with an emphasis on the family Blechnaceae. Ph.D. thesis, University of California, Berkeley.

Croft, J.R. 1986. The stipe and rachis vasculature of the dicksonioid fern Cystodium sorbifolium (Cystodiaceae). Kew Bulletin, 41: 789-803.

Degener, O. 1934. Flora Hawaiiensis or the illustrated flora of the Hawaiian Islands. Honolulu, Hawaii.

\section{How to cite this article:}

Teena Agrawal and Priyanka Danai. 2017. Fossil Pteridophytes-A Review. Int.J.Curr.Res.Aca.Rev. 5(6), 86-92. doi: https://doi.org/10.20546/ijcrar.2017.506.012 